\title{
Local Agroforestry as Landslide Mitigation in the Gede Catchment in Malang Regency
}

\author{
Nurul Muddarisna ${ }^{1}$, Eny Dyah Yuniwati ${ }^{2}$, Heni Masruroh ${ }^{3}$, Aulia Rahman $\mathrm{O}^{4}$ \\ \{ Nurulmudarisna@yahoo.co.id ${ }^{1}$, nieyuniwati@gmail.com ${ }^{2}$, henimasruroh11@gmail.com ${ }^{3}$ \} \\ ${ }^{1,2,3}$ Agriculture Faculty, Wisnuwardhana University of Malang \\ ${ }^{4}$ Engineering Faculty, Wisnuwardhana University of Malang
}

\begin{abstract}
Gede catchment is the part of Bromo Volcano System. It is located in the Malang Regency, East Java Province. The wide of Gede Catchment is around $17 \mathrm{Km}^{2}$. Based on the landslide prone area mapping, this area has high potential landslide around $52,9 \%$. There were several landslides which had been occurred in this area. Based on the physical condition, this area is rather not appropriate for living. In the other hand, the community had been survived to live in harmony with high potential landslide prone area. The aim of paper is to elaboration of community adaptation strategies which had been survived in landslide prone area.The method was carried by field survey including observation and in-deep interview to the Gede Catchment's community regarding adaptation strategies for surviving to live harmony with high potential landslide prone area. Field survey for data collection was carried out by grounded research technique.Based on the real condition, the Gede Catchment's community had been survived to live in harmony with high potential landslide prone area. They were very much aware on their living environmental as well as their economic income. Mostly, the community planted several local plantation (agroforestry system) in the inactive landslide (ex-landslide area) and active landslide. It is as the solution between how conserving the landslide prone area with the sustainable economic income. The plantation is the effective protection to soil movement
\end{abstract}

Keywords: Community, Adaptation, Landslide, Gede Catchment.

\section{Introduction}

Generally, the physical of geomorphology condition will has affect for living of society. Extreme geomorphological process can be risk for sustainable living of society. Geomorphology process embedded at our physical environment that modify our land characteristic along the time [1].The geomorphological process will happened at small scale area and large scale area due to human activities area. As human who living in this area will have challenge how to be surviving including how to conserve their environment.

Landslide disasters are the most common disaster in Indonesia. According DIBI data 2019 [2], there were 512 landslides that occurred in Indonesia. Landslide event usually occurs during the peak of wet season and in the hilly area [3]. The threat of landslides is currently getting higher by the rising population whose lives are at stake as they live on the slopes inhilly area. Geomorphology as one of triggered factor to landslide occurred [4]. Commonly, landslide will be occurring in the rough geomorphology. But in the other hand, landslide and geomorphology process can accelerated by human activities[5]. Mostly, the society using mechanical and vegetative conservation and combining both of them to conserve their environment. They neglected the soil characteristic. It will increase the landslide potential. For 
the rough geomorphology needs the particularly treatment to decrease the landslide occur. The treatments have to consider the physical soil condition, local agroforestry and economic income of the society. It is become important because the best conservation for sustainability is how to combine these all. Landslide mostly has been addressed by land management.

In several cases, the society planted the woody plants in landslide prone area [6]. They are not considering the soil condition and economic income of the society. It is become important for conserving landslide because the best conservation is how to combine of physic soil condition, local agroforestry and surviving economic income of society. The woody plants which planted in the thick soil in the rough geomorphology will trigger of landslide occurs. The woody plants will increase the soil mass, thus the landslide potential will increase also. Landslide conservation without consider soil condition will trigger of landslide.

Local behavior in preserving their living environment as strategy adaptation for landslide conservation might be the best way as the best solution which considering soil condition, local plantation of agrofrestry system and sustainability economic income, however the community has no sufficient knowledge to explain their community adaptation strategies. The societies of Gede Cathment have been living successfully with extreme of geomorphological process in their environment such landslide. They have local strategy as adaptation for their environment that has high potential landslide. They are introducing of new strategy adaptation for landslide prone area with the local agroforestry plant. It is based on the society local knowledge. There were some important values of the local environments that have been neglected and presumed belonged to the similar systems of the new model. The local society may have the best knowledge of their living environments [7]

Conservation based on the local agroforestry, soil condition and giving economic income for the society is still rare to do in several landslide prone areas and rough geomorphology. The research objective of this research is to elaborate community adaptation strategies in landslide prone area of Gede Catchment.

Gede catchment is the part of Bromo Volcano System. It is located in the Malang Regency, East Java Province. The wide of Gede Catchment is around $17 \mathrm{Km}^{2}$ (Fig.1). Its located in the middle slope of Bromo Volcano Mountain. The subsurface material is dominated by deposition of Bromo Volcano material.
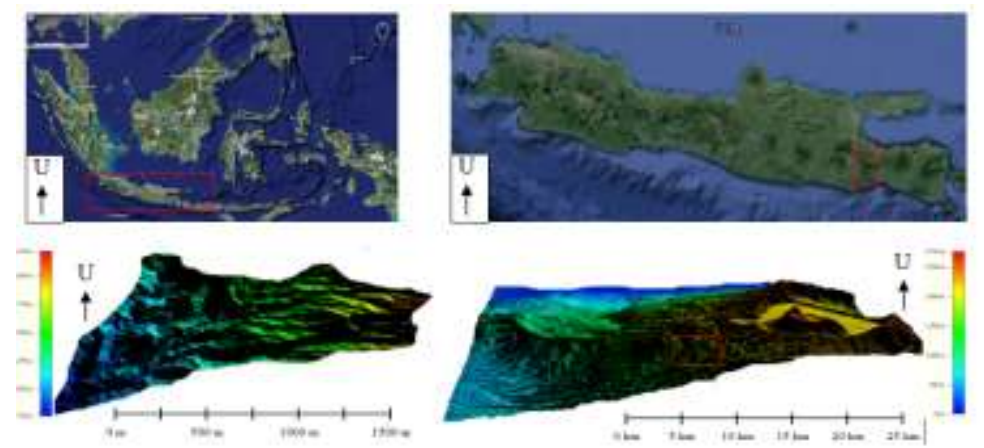

Fig. 1: The Study Area

\section{Research Method}

The data which used in this research is DEMNAS data. The elevation data is the necessary for making landslide susceptibility map which created by geomorphometric approach involves 
several steps i.e 1) DEM download processing; 2) DEM processing, 3) landslide susceptibility map processing, 4) Field check and 5) layout landslide susceptibility map. DEM processing was done by Integrated Land and Water Information System (ILWIS) open source software. DEM processing has produced several thematic for making landslide susceptibility map i.e plan curvature, profile curvature, mean curvature, slope, and elevation. Each thematic map has an influence to landslide

The field survey was done for accuracy of landslide susceptibility map and observation of some local effort to control landslide as well as socio economic assessment. The fields survey including observation the kind of local agroforesty or local plantation which had been growth in each morphology. The grounded research was done to observe the local community behavior in their environment including planting, managing and harvesting the local plantation. The field survey also completed with in depth interview local society.

The result of this research is formulated strategy adaptation of community which focused on agroforestry or local plantation as conservation landslide prone area and economic income preservation. The formula scientific explanation is based on literature study which had been mixed with the real condition. We found several fact that the local agroforestry in the Gede Cacthment could be conserve the landslide prone area.

\section{Result and Discussion}

\subsection{Landslide characterization in the study Area}

Landslide as the natural disaster has characterization including their physiographic characteristic. It will influence to how to conserve soil as material of landslide. The characterization of landslide that has significant influence of landslide i.e surface material, landuse, slope and rainfall which have significant influence each others. Landslides will increase in thick soil material and unconsolidated soil [8]. Inappropriate of land use on thick soils which has high inclination of slope will increase the potential for landslides. Land use has an effect on soil mass loads [9]. If land use exceeds the threshold of land mass load, the potential for material movement of the soil increases during the rainy season.

The physic condition of study area of landslide is in the Bromo Volcano system. Its located in the upper slope of Bromo Volcano. Mostly, the morphology of the study area is middle slope. The subsurface material is dominated by deposition of Bromo Volcano and it has thick soil. It can be observed by identified of landslide scarp. The elevation in the study area until 2761 mean sea level. Whereas, for the slope until 15 degree. It makes this area has high potential landslide.

Landslide was becoming the environmental problem in the study area. There have been several landslides in this area which have caused losses in agriculture and damage to roads and settlements. The inclination and the thick soil condition become the most influencer to landslide occurrence. In addition, the cut of slope inclination more than $15 \%$ also become the main factor. It makes unstable slope, thus it will increase the landslide potential.

The typology of landslide in the study area is rotational and translational landslide (Fig 2). Both of landslides are including active and inactive landslide and it is used for land farming with the local agroforestry plantation. Each landslide type has their own characterization based on the road association, river and local agroforestry in the landslide's body. Mostly, the body of inactive rotational landslide is used land farming with vegetation like carrot, potato, apple, coffee, and broccoli. The society were used this inactive landslide because the material of 
landslide makes the surface material more fertile. Whereas, for the active rotational landslide with cassava vegetation. The body of translational active landslide is not used because the shape of landslide body is planar, steep slope, and having lower density vegetation and the soil material is thinner than the body of rotational landslide. Mostly, the typology of landslide in the study area is the rotational landslide.

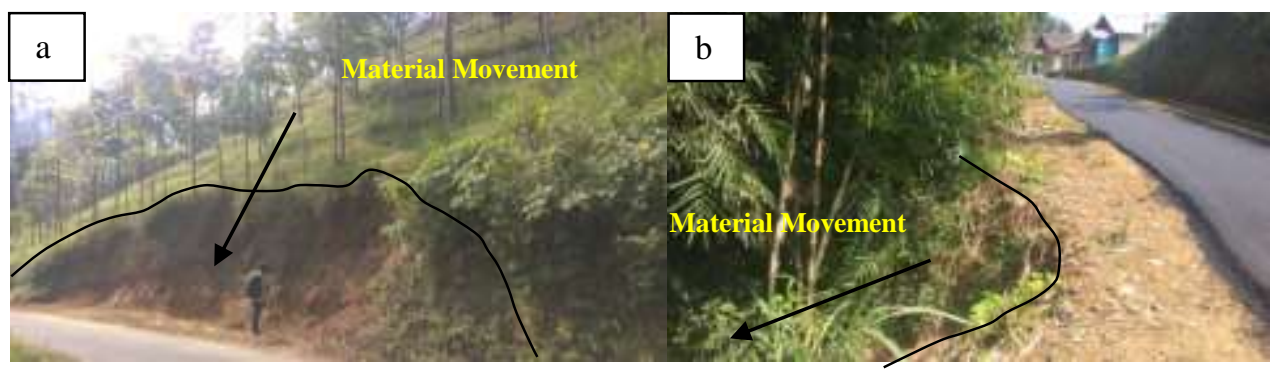

Fig. 2: Typology Landslide (a) Rotational landslide; (b) Translational landslide

Based on the landslide susceptibility mapping this area consist stable zone such landslide area and unstable zone. For the stable zone is in the peak interfluves and foot slope (Fig.3), Both of them has low slope thus there are not energy to move the soil material. Whereas, for the unstable zone is started from upper slope until lower slope. The topographic position of the slope is started from peak interfluves until channel bad. Soil material starts to move in the topographic position of the upper slope. The geomorphological process found on the upper slope as an indicator of movement of soil material is the presence of cracks (soil cracks) and erosion. Both geomorphological processes can initiate the movement of soil material, so that it can initiate material movements [10]. The topographic position of the slope that has no force to move the material, namely alluvial and colluvial plains. The topography of the Gede Catchment is largely unstable because of slope cutting for road and river.

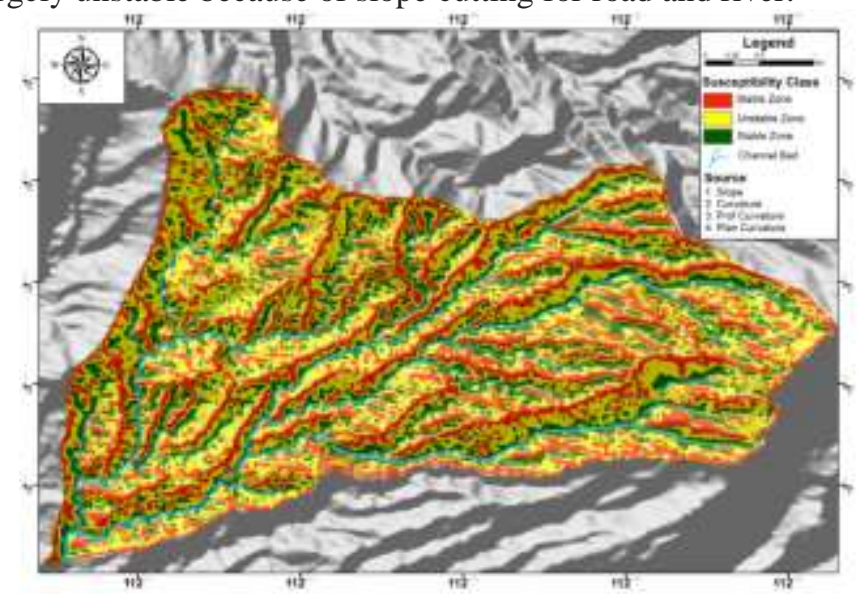

Fig. 3: Landslide Susceptibility Map 


\subsection{Local Plantation (agroforestry system) in the study area}

The livelihood had been developing in the Gede Catchment are mostly reflected by agroforestry system. Almost all the agro-forestry in the study are which developed by the Gede Catchment's society are for increasing their economic income. Mostly, the local agro-forestry plantations in the study area are mixed garden with the local plantation such clove, coffee, apple, carrot, cassava and local holticulture plantation. All these for increasing the economic income of Gede Catchment's community with categorized daily income, weekly income, monthly income and annual income. All these based on timing of harvest.

The local plantation had been managing with agricultural settings. It means that the local plantation in the study area are based on the ecologically and natural resource management system. Both of them were consider to increase economic income and environmental sustainability. Agroforestry with local mixed gardens can be one of the solutions in environmental management [9]. This happens because plants are one of the factors that have an influence on soil conditions. This includes influencing the infiltration process, run off, and soil mass load. Mostly, the land without vegetation has a greater run-off than infiltration. This affects the process of moving soil material during the rainy season.

Agroforestry is a perennial forest management system combined with agriculture system. Thus, agroforestry plantation can be in the form of forest plants (woody plants) and agricultural crops including horticulture and secondary crops. Mixed garden is the agroforestry that was implemented in the study area. The society of Gede Catchment practiced the mixed garden for economic income and one of the ways for landslide conservation, particularly vegetative conservation. They assume that mixed garden is the solution provides economic and environmental benefits.

Landslides as one of the geomorphological processes can be influenced by human activities [11]. It means landslides can occur because they are initiated by humans, but humans can also make conservation efforts through various means as mitigation efforts and reducing the risk of landslides. Community behavior in managing land is the main factor which has influence environmental condition. Therefore, environmental condition has affected and has strongly linked with the human behavior.

Gede Catchment's society had been awareness of living in the study area that has high potential of landslide. The community more selective for determining the type of vegetation in the each unit morphology and considering land cultivation and land uncultivation. Both of them has influence to landslide potential occur. The inclination of slope will be changes if the landslide occurs. It will affect to soil erodibility, run off, and infiltration. The society of Gede Catchment had limited utilize the land that has high slope inclination. As far, the societies don't use the landslide scarp for cultivation. They just cultivated the depositional part of landslide. Nevertheless, the community cannot plant plants carelessly without considering the type and unit of morphology. Communities may only plant several types of plants in certain morphological units. This is important because the type of plant will affect the mass load of the soil.

The land utilization in the Gede Catchment shows spatial arrangement based on physical characteristic in the study area. The spatial arrangement are including type of vegetation, unit morphology and landslide site. The type of vegetation such bamboo, clove and other woody plants has planted in the peak interfluves. The mixed garden such combining of coffee plantation with the holticulture plant such carrot, apple, potato was applied in the upper slope until lower slope. For the foot slope was applied for seasonal vegetation (Fig.4) 

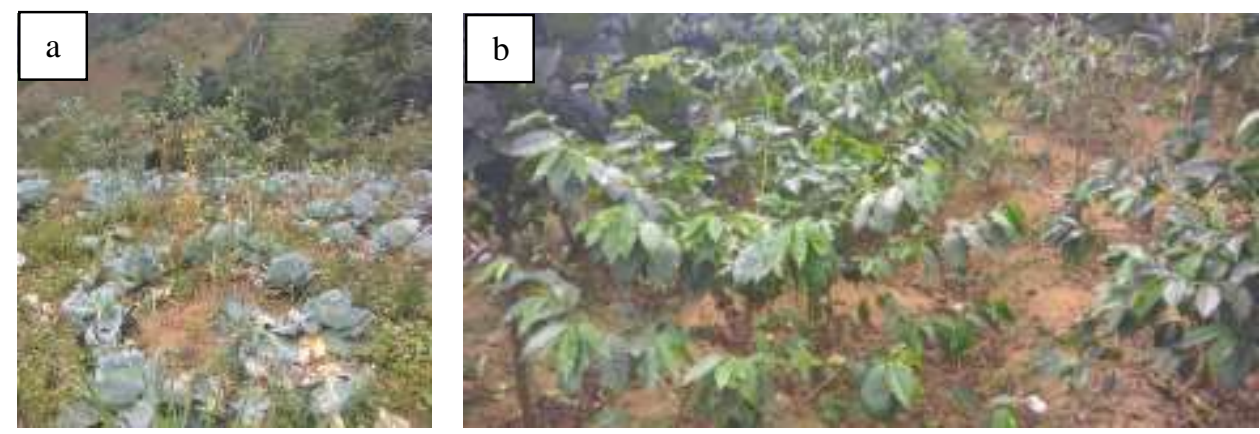

Fig 4: Local Plantation in the Gede Catchment (a) Agroforestry such Apple, Cabbage, Onions, Tomatto; (b) Chili and Coffee

The spatial arrangement also applied in the landslide site. There are differences between spatial arrangement in active landslide and inactive landslide. For the active landslide the type of vegetation just grown naturally without planted by society. It will differences with the inactive landslide. Mostly, the society planted several local agroforestry plantation in the spatial arrangement of landslide site. At the crown area, the society planted woody plantation such clove and bamboo. The society has assumed that these plants could conserve the soil movement. But, in fact in the study area the landslide still occurs. Generally, the woody plantation could conserve the soil movement, but it is not appropriate in the study area because the study area has thick soil. Thus, it makes the wood plantation as triggers of landslide because this exceeds the soil mass load. At the landslide body, the society plant holticulture plants such apple, carrot, cassava and coffee with the terrace technique. In the toe of landslide, the society plant the mixed garden also with the type of vegetation such chili and tomato. The spatial arrangement between type of vegetation with the landslide site and unit morphology as community adaptation in the landslide prone area.

\subsection{Fact Finding Local Agroforestry as Community Adaptation for Landslide in the study area}

Generally based on the theory, woody plantation could be landslide conservation. But, we found that it could not be applied in the study area. For the landslide conservation considering the soil physical condition and the type of plantation is necessary. For the area that has thick soil such in the study area, woody plantation is not appropriate for landslide conservation. It will increase the soil mass load. The spatial arrangement between type of vegetation, unit morphology and landslide site is the solution for adaptation of landslide in the study area. The community of Gede Catchment has adaptation for landslide based on morphology unit. At the peak interfluve, the community planted the woody plants such bamboo, for upper slope until middle slope the community planted horticultura such tomatoes, apples, coffee, and onions. Whereas, for the foot slope planted carrot and eggplants. All these are planted in the one slope morphology (Fig. 5). The community planted these all consider economic and environmental conditon. 


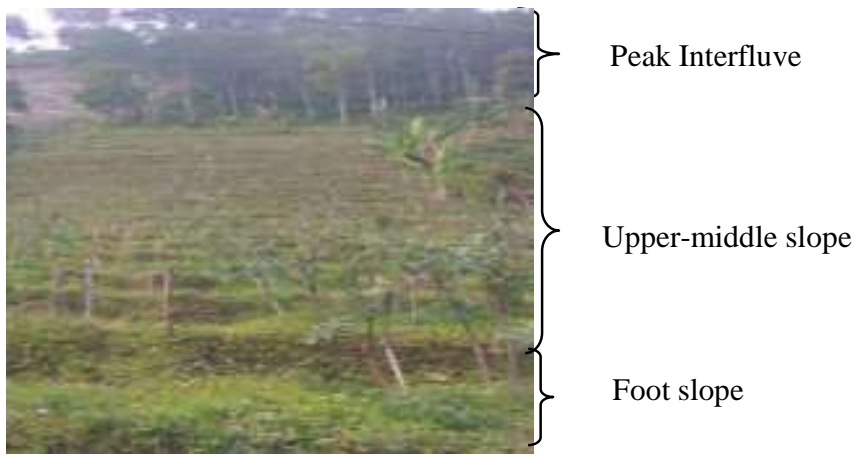

Fig 5: The Community Adaptation for Landslide at single slope

The woody plants which planted in the peak interfluves is appropriate because in this unit morphology has flat surface, so it does not have energy to soil movement. The mixed gardern with the holticulture plants were applied in the part of slope i.e upper slope, middle slope, lower slope and foot slope respectively which gets fewer disturbances to the natural land system. The intensive land management in the foot slope would not more affect for landslide. The terrace technique which applied in the upper slope until foot slope has affected for landslide occur. The terrace technique will decrease run off and collect the water, thus it will decrease soil movement also. Considering the type of vegetation for landslide area is the necessary because the plants could be conserve the soil and environmental condition.

\section{Conclusion}

The study area is the mountainous area that has high potential of landslide and intensively for agriculture. As far, the societies are very aware how to conserve their environment. They had been planting local plantation with the agroforestry system and considering the unit morphology and landslide site as adaptation strategy. This strategy adaptation had been considerate the economic income and environmental conservation. The very appropriate conservation is combining environmental aspects and community income. Sometimes, conservation that appropriate for the environment but does not support community income could not apply for a long time.

For the recommendation, to decrease the landslide potential we have to consider the type of vegetation which adapted with the unit morphology and mixed garden are recommended. The vegetation in the peak interfluve could be plant such bamboo and sengon, for the upper until middle slope horticultura plantation such tomatoes, apples, chilies, and onions. Whereas, for the foot slope could plant such eggplants and carrots. The mixed garden with the stratified plantation and considering unit morphology and landslide site is the best appropriate for landslide conservation. In addition, we have to consider the land management and timing of harvest plantation. Planted the monoculture or single plantation have to avoid in the landslide prone area. It will better to plant stratified plantation started from ground cover, foot slope, middle slope, upper slope and peak interfluves. 


\section{Acknowledgment}

Thanks for the Ristekdikti (Directorat Research and Strengthening and Development) who has funded this research and also LPPM Universitas Wisnuwardhana Malang that support during proposal submission until doing the research

\section{References}

[1] J. Szabó, L. Dávid, and D. Lóczy, Anthropogenic geomorphology: a guide to manmade landforms. Springer Science \& Business Media, 2010.

[2] DIBI, "Data Bencana," 2016. [Online]. Available: https://bnpb.cloud/dibi/laporan5 . [Accessed: 26-May-2019].

[3] O. Igwe, "The geotechnical characteristics of landslides on the sedimentary and metamorphic terrains of South-East Nigeria, West Africa," Geoenvironmental Disasters, vol. 2, no. 1, p. 1, 2015.

[4] G. Qiao et al., "Landslide investigation with remote sensing and sensor network: From susceptibility mapping and scaled-down simulation towards in situ sensor network design," Remote Sens., vol. 5, no. 9, pp. 4319-4346, 2013.

[5] P. L. Barnard, L. A. Owen, M. C. Sharma, and R. C. Finkel, "Natural and humaninduced landsliding in the Garhwal Himalaya of northern India," Geomorphology, vol. 40, no. 1-2, pp. 21-35, 2001.

[6] Y.-C. Chen, C.-F. Wu, and S.-H. Lin, "Mechanisms of forest restoration in landslide treatment areas," Sustainability, vol. 6, no. 10, pp. 6766-6780, 2014.

[7] G. Tuladhar, R. Yatabe, R. K. Dahal, and N. P. Bhandary, "Disaster risk reduction knowledge of local people in Nepal," Geoenvironmental Disasters, vol. 2, no. 1, p. 5, 2015.

[8] G. Wang et al., "Layered internal structure and breaching risk assessment of the Higashi-Takezawa landslide dam in Niigata, Japan," Geomorphology, vol. 267, pp. $48-58,2016$.

[9] V. H. D. Zuazo and C. R. R. Pleguezuelo, "Soil-erosion and runoff prevention by plant covers: a review," in Sustainable agriculture, Springer, 2009, pp. 785-811.

[10] サモドラグル, “DEVELOPMENT OF RISK ANALYSIS TECHNIQUE AND ITS APPLICATION TO GEO-DISASTER MANAGEMENT IN INDONESIA.” 九州大 学, 2014.

[11] T. Preuth, T. Glade, and A. Demoulin, "Stability analysis of a human-influenced landslide in eastern Belgium," Geomorphology, vol. 120, no. 1-2, pp. 38-47, 2010. 